Poznań

\title{
Serbian elections: The path towards Europe?
}

\begin{abstract}
The Republic of Serbia was established on 5 June 2006 as a legal successor to the state of Serbia and Montenegro which dissolved after Montenegro had declared independence on 3 June 2006. Serbia and Montenegro were constituted as a union of two republics on 4 February 2003 and replaced the Federal Republic of Yugoslavia. The latter was created on 27 April 1992 and was composed of the Republic of Serbia and the Republic of Montenegro.This article has as its main goal to answer the following questions: Will Serbian elections ensure the country's continued path toward Europe and is Serbia ready for EU membership? Serbia's integration with the European Union strengthened after proEuropean Boris Tadić was elected the country's president in 2004. The largest hurdles to Serbia's EU accession are, firstly, the issue of Kosovo's independence, and, secondly, putting those responsible for war crimes in former Yugoslavia on trial before the Hague Tribunal. Serbia's EU integration process has been quite protracted and the country would like to finish its negotiations by 2019 in order to join the European Union officially in 2020. The European Commission has declared a moratorium on accession of new members during the current term of both the Commission and the European Parliament, which will expire in 2019. In April, Ivica Daczić and Hashim Thaci signed a negotiated agreement under the EU auspices to normalize the relations between the two countries. Kosovo, a former Serbian province mostly populated by Albanians, declared independence in 2008, which Belgrade has never recognised. The agreement does not provide for Serbia's formal recognition of Kosovo's sovereignty, but it regulates the situation in northern Kosovo which has a 40,000-strong Serbian minority. Both parties have also agreed not to block each other on their path to EU membership.
\end{abstract}

Key words: Serbian elections, parties, European Union, Kosovo

$\mathbf{T}$ he transition processes in post-Yugoslav states are far more complicated than in other East European countries. One example of those processes is the Republic of Serbia. The 1990s were dominated by the authoritarian rule of Slobodan Milošević (See Korzeniewska-Wiszniewska, 2008 for more detail) and the country's participation in armed conflicts (See Mihajić, 2008 for more detail). The ensuing sanctions and NATO's military intervention in 1999 only made worse what was already a very difficult economic situation after the collapse of communism. As a result, strong ties developed between the country's political elites and its power structures and criminal organisations. This hampered the transformation process after Slobodan Milošević was removed from power in 2000 .

In 2000, Serbia was included in the Stabilisation and Association Process (SAP), a policy measure established to support internal reforms, grant trade preferences and, eventually, offer EU membership to the countries involved (Komunikat Komisji...). It was not until 2009 that Serbia finally applied for EU membership. The reasons for the slowdown in the EU integration process in the $21^{\text {st }}$ century's first decade were unstable borders, failure to reach a consensus over the integration, and a slow pace of reforms. In 2000, Serbia, Montenegro and Kosovo together formed what was known as the Federal 
Republic of Yugoslavia. However, both Kosovan and Montenegrin elites wanted independence. Montenegro declared independence in 2006 and the process that had led to it was one of negotiated relaxation of ties between Belgrade and Podgorica (Lubik-Reczek, 2011). Kosovo, on the other hand, declared its independence in 2008 and this happened against Serbia's will and without its consent. Furthermore, some Parliamentary groups, both in opposition and different coalition governments, were rather ambivalent about the EU integration and democratic transformation processes. This became particularly apparent after the assassination of Zoran Đinđić in 2003 and the lack of cooperation with the International Criminal Tribunal for the former Yugoslavia (ICTY), which was a major prerequisite at the time to any further EU integration.

The Republic of Serbia was established on 5 June 2006 as a legal successor to the state of Serbia and Montenegro which dissolved after Montenegro had declared independence on 3 June 2006. Serbia and Montenegro were constituted as a union of two republics on 4 February 2003 and replaced the Federal Republic of Yugoslavia. The latter was created on 27 April 1992 and was composed of the Republic of Serbia and the Republic of Montenegro (Ibidem).

This article has as its main purpose to answer the following questions: Will Serbian elections ensure the country's continued path toward Europe and is Serbia ready for EU membership? Serbia's integration with the European Union strengthened after pro-European Boris Tadić had been elected the country's president in 2004. The largest hurdles to Serbia's EU accession are, firstly, the issue of Kosovo's independence, and, secondly, putting those responsible for war crimes in former Yugoslavia on trial before the Hague Tribunal.

In accordance with its Constitution of 8 November 2006, as endorsed in a national referendum on 28-29 October 2006, the Republic of Serbia's head of state is its president who is elected in general elections for five-year terms. The country's legislative powers are vested in a unicameral parliament called the National Assembly of Serbia and composed of 250 deputies elected in general elections for four-year terms. Executive power is exercised by a government headed by a prime minister who is nominated by the parliament. Cabinet members are nominated by the prime minister and confirmed by the parliament. The Serbian Constitution continues to refer to Kosovo as an integral part of Serbia. Since mid-1999, Kosovo was a UN-administered autonomous region of Serbia. ${ }^{1}$ After months of unsuccessful negotiations on the status of Kosovo, the Kosovan parliament, by acclamation, declared the country's independence on 17 February 2008. One day after it happened, on 18 February 2008, the Serbian parliament rejected the proclamation of Kosovo's independence and has not recognised it to date.

On 8 March 2008, the then Serbian prime minister tendered his resignation. Early elections followed on 11 May 2008 (almost 16 months after the last election on 21 January 2007) with $6.7 \mathrm{~m}$ eligible voters deciding on who would become elected to the 250-seat parliament (See Republika Serbii... for more detail). The election also doubled as a referendum for the country's citizens to decide on their EU membership. Serbian ultranationalists tapped into a resentment which some in the general public felt against

${ }^{1}$ The country's area (including Kosovo) is $88,361 \mathrm{~km}^{2}$, and population: 10,159,046 (https://www. cia.gov/library/publications/the-world-factbook/index.html, as at 16 Nov 2009). 
the USA and EU after they endorsed the independence of Kosovo which Serbians sees as the cradle of their statehood. On 29 April, in an effort to support the pro-European forces within Serbia, the European Union signed a conditional association and cooperation agreement with the country.

Table 1

Parliamentary parties after the 2008 election

\begin{tabular}{|l|c|c|}
\hline \multicolumn{1}{|c|}{ Electoral list } & \% & Seats \\
\hline For a European Serbia - Boris Tadić & 38.42 & 102 \\
\hline Serbian Radical Party - Dr Vojislav Šešelj & 29.46 & 78 \\
\hline Democratic Party of Serbia and New Serbia - Vojislav Koštunica & 11.62 & 30 \\
\hline SPS - PUPS - US & 7.58 & 20 \\
\hline Liberal Democractic Party - Čedomir Jovanović & 5.24 & 13 \\
\hline Hungarian Coalition - István Pásztor & 1.81 & 4 \\
\hline List for Sandžak - Dr Sulejman Ugljanin & 0.92 & 2 \\
\hline Albanian Coalition of Preševo Valley & 0.41 & 1 \\
\hline Total & & $\mathbf{2 5 0}$ \\
\hline Turnout & $\mathbf{6 1 . 3 3}$ & - \\
\hline
\end{tabular}

Source: Own study based on www.rik.parlament.gov.rs, 28 March 2015.

The result made it clear that the majority of Serbs supported their country's effort to integrate with the EU. That said, the general public, just as the country's political scene, is clearly divided into two camps: one "pro-Western" and pro-integration, and the other composed of nationalists who oppose Serbia's membership of the EU or NATO and advocate closer ties with Russia.

The next parliamentary election was held after four years, on 6 May 2012. For the first time in the $21^{\text {st }}$ century, this was Serbia's first election held within its set term. The contest was held simultaneously with the first round of the presidential election. In the second round of that election, the incumbent president Boris Tadic of the Democractic Party lost to the leader of the Serbian Progressive Party, Tomislav Nikolić. The Serbian Progressive Party-led coalition was ahead of the presidential bloc by less than two percentage points. The new coalition government was formed by the new president's Socialist Party of Serbia and its partners - G-17 Plus and social democrats. For the first time, the Serbian Radical Party, weakened by internal splits, did not get into the parliament. Following two months of negotiations, the progressives formed a collation government which the Socialist Party of Serbia whose leader, Ivica Dačić, became prime minister. Former President Boris Tadić's Democratic Party, then in government with the socialists, moved to the opposition benches and got a new leader - mayor of Belgrade Dragan Đilas. Over the following months the Democratic Party experienced a number of feuds and splits within its ranks, and its leader was removed from mayorship. Given the Serbian Progressive Party's ever improving rankings, its leader, first deputy prime minister Aleksandar Vučić called for early elections. The proposal was endorsed by prime minister Ivica Dačić. On 29 January 2014, President Tomislav Nikolić dissolved the National Assembly and called for elections to be held on 16 March 2014. 
The Republic Electoral Commission registered 19 electoral lists:

1. Aleksandar Vučić - Future We Believe In (Serbian Progressive Party, Social Democratic Party of Serbia, New Serbia, Serbian Renewal Movement, Movement of Socialists);

2. Ivica Dačić - Socialist Party of Serbia (SPS), Party of United Pensioners of Serbia (PUPS), United Serbia (JS);

3. Democratic Party of Serbia - Vojislav Koštunica;

4. Čedomir Jovanović - LDP, BDZS, SDU;

5. Alliance of Vojvodina Hungarians - István Pásztor;

6. Serbian Radical Party - Dr Vojislav Šešelj;

7. United Regions of Serbia - Mlađan Dinkić;

8. Democratic Party for a Democratic Serbia;

9. Dveri - Boško Obradović;

10. Party of Democratic Action of Sandžak - Dr Sulejman Ugljanin;

11. Boris Tadić - New Democratic Party - Greens, LSV - Nenad Čanak, Together for Serbia, VMDK, Together for Vojvodina, Democratic Left of Roma;

12. Third Serbia - For All The Hard-Working People;

13. Montenegrin Party - JOSIP BROZ;

14. All Together - BDZ - MPSZ - DZH - MRM - MEP - Emir Elfić;

15. It's Enough - Saša Radulović;

16. Coalition of Citizens of All Nations and National Communities (RDS-SDS);

17. Civic Group "Patriotic Front - Dr. Borislav Pelević";

18. Russian Party - Slobodan Nikolić;

19. Party for Democratic Action - Riza Halimi.

The official results were announced on 24 March 2014, with the Serbian Progressive Party, SDPS, New Serbia, Serbian Renewal Movement, and Movement of Socialists winning 158 seats ( $48.35 \%$ of the vote). The Socialist Party of Serbia, Party of United Pensioners of Serbia, and United Serbia came in second winning 44 seats; Democratic Party for a Democratic Serbia won 19 seats; New Democratic Party, LSV, ZZS, VMDK, ZZV, and DLR won 18 seats; Alliance of Vojvodina Hungarians won 6 seats; Party of Democratic Action of Sandžak won 3 seats; and the Party for Democratic Action won 2 seats (Serbia: oficjalne...).

The leader of the progressive coalition, Aleksandar Vučić, took the helm of the new government, which also included socialists from the then prime minister Ivica Dačić's coalition. The support for SNS stood at about $50 \%$ and the prime minister continued to top the rankings as the country's most popular politician. An early January 2016 opinion poll by Faktor Plus predicted that progressives would win more than $51 \%$ of the vote, with support for all the other parties hovering at no more than 10\%. On 17 January 2016, Aleksandar Vučić called for an early parliamentary election, arguing that Serbia needed a stable government in the next four years to meet the conditions for the EU accession within that time. On 4 March 2016, President Tomislav Nikolić (SNS founder and former leader) decided that the election would be held on 24 April 2016.

For Serbia, the early parliamentary contest "was a step towards the European standard of living." The current prime minister Aleksandar Vučić's pro-European party won the election, winning 131 seats (48.25\%) (Proglasena prva lista...). The bloc won the 
absolute majority in the National Assembly (See: SNS i Vucicic... for more detail on the post-election reactions). Nevertheless, the bloc lost some seats because the other parties passed the required electoral threshold. The coalition of four parties - Socialist Party of Serbia, United Serbia, the Geens of Serbia and the Communist Party of Serbia - won 29 seats $(10.95 \%)$. SPS leader and current foreign minister Ivica Dačic supports cautious integration with the EU on condition that Belgrade's relations with Moscow and Beijing do not suffer as a result. The election also saw Vojislav Šešelj's pro-Russian and eurosceptic Serbian Radical Party enter the Parliament with 22 seats (8.10\%) (Ibidem). Šešelj is an advocate of creating Greater Serbia, an entity similar to former Yugoslavia. He was acquitted by the Hague Tribunal on all counts of war crimes and crimes against humanity during the Balkan wars of the 1990s. The party's main objective is to defend the Constitution in order to put a stop to dangerous changes which Western states want to impose on Serbia. The acquittal of the Serbian Radical Party's leader breathed a new life into the party which was then seen as a relic of the past. The party's entry into the Parliament is also a reflection of divisions within the Serbian society in which 10-15 per cent of the population espouses radical views. The other parties which entered the parliament are: the Democratic Party coalition $(6.02 \%, 16$ seats), Dosta je bilo $(6.02 \%, 16$ seats), LDP-LSV-SDS (5.02\%, 13 seats), and Dveri-DSS (5.04\%, 13 seats). 10 seats were won by candidates from four minority lists.

\section{Cooperation with the International Criminal Tribunal for the former Yugoslavia}

The International Criminal Tribunal for the former Yugoslavia (ICTY) was established on 25 May 1993 under UN Security Council Resolution 827. The Tribunal has jurisdiction over the following crimes committed on the territory of the former Yugoslavia since 1991: grave breaches of the Geneva Conventions of 12 August 1949 for the Protection of Victims of War (Journal of Laws of 1956, No. 38, item 171); violations of the laws or customs of war; genocide; and crimes against humanity (Śliwa, 2008).

For the European Union, any advance in Serbia's integration process depends on the country accounting for its past war crimes. First and foremost, this requires an effective cooperation with the International Criminal Tribunal for the former Yugoslavia. What best exemplified this cooperation were arrests of persons sought by the Tribunal, such as the former leader of Croatian Serbs Goran Hadžić (2011), Radovan Karadžić (2008), Slobodan Milošević (2001) and, most importantly, Ratko Mladić (2011). The arrest of Mladić, who was the commander of the Serbian military, was of particular importance to the Netherlands whose soldiers were present in Srebrenica and which therefore felt responsible for seeking the conviction of all those responsible for that massacre (For more detail, see: Serbia: aresztowanie...;Korzeniewska-Wiszniewska, 2008, Mihajić, 2008).

The cooperation with ICTY is problematic for Serbia for a number of reasons.

Firstly, even though Slobodan Milošević was removed from power in 2000, most of those with ties to his former regime have kept their ministerial positions, which meant those wanted for arrest could successfully hide in Serbia. 
Secondly, a considerable part of the right-leaning political elites, including former prime minister Vojislav Koštunica (2004-2008), opposed extradition of Serbian citizens to the Hague, believing that they had defended Serbian territorial integrity and protected persons of Serbian origin during the war.

Thirdly, the Serbs themselves are ambivalent about the Tribunal and its actions. Many in Serbia believe that the Tribunal is not fair and impartial as its major preoccupation is with seeking convictions for people of Serbian origin, while disregarding crimes committed on Serbs.

Failure to cooperate with the International Criminal Tribunal for the former Yugoslavia meant that the EU integration processes has often stalled. In 2006, the EU suspended its SAA negotiations for over a year, and only resumed them in June 2007 following the arrests of Zdravko Tolimir, who was accused of involvement in the Srebrenica massacre, and of Vlastimir Đorđević, who was suspected of committing war crimes in Kosovo in 1999. The lingering doubts about Serbia's commitment to cooperation with the Tribunal also had the effect of postponing and accepting the country's accession application. The arrest of Ratko Mladić on 26 May 2011 has finally removed the hurdles in the EU integration process (For more on Serbia's EU integration, see Lubik-Reczek, 2011).

\section{Relations with Kosovo}

On 17 February 2008, Kosovo proclaimed independence and de facto confirmed its full autonomy from Belgrade. The decision met with strong opposition from Serbia. 22 out of 27 EU Member States recognised Kosovo as an independent country. Romania, Spain and Cyprus did not recognise its sovereignty, whereas Greece and Slovakia chose not to address the matter officially.

On 22 July 2010, the International Court of Justice at The Hague delivered a split opinion holding that Kosovo's declaration of independence was not against the letter of international law. In the statement of reasons, the ICJ declared that "international law contained no prohibition of declarations of independence." (Kownacki, Żornaczuk, 2010). Importantly, the ICJ did not render a judgment on the question of Kosovo's independence but an advisory opinion. The opinion has no legal force and only serves as ICJ's interpretation of a specific legal situation. Serbia will not accept the sovereignty of its former province, especially that it holds a place which Serbs believe is the cradle of their statehood. In its opinion, the court in The Hague held that Kosovo's declaration of independence did not fall foul of international law. In other words, it was in accordance with international law, and the people of Kosovo had the right to declare independence.

Four days after the event, an extraordinary session of the Serbian parliament was convened and a resolution adopted stating that Serbia would never recognise Kosovo's independence. Out of 250 deputies, 192 voted for the resolution as it was worded, 26 deputies were against it, and two deputies abstained (For more detail, see Szpala, 2010).

On 22 October 2010, Kosovo confirmed its readiness to hold talks with Serbia under the EU auspices. The talks between Belgrade and Pristina began on 8 March 2011 in Brussels. Before the meeting, EU foreign policy chief Catherine Ashton confirmed that 
the talks would be an opportunity for Belgrade and Pristina to bring them closer to the European Union.

The issue of Kosovo is a serious hurdle on Serbia's road towards the European Union. The EU have signalled on many occasions that it is not ready to offer membership to Serbia unless the country normalises its relations with Kosovo.

\section{Summary}

Serbia's EU integration process has been quite protracted and the country would like to finish its negotiations by 2019 in order to join the European Union officially in 2020. The European Commission has declared a moratorium on accession of new members during the current term of both the Commission and the European Parliament, which will expire in 2019. Serbia will also need to continue its economic and political reforms. Recently, the country has caught attention of the likes of Siemens and Microsoft in the high technology sector, of US Steel in heavy industry, and of French-based Lafarge in construction. That said, these are still declarations rather than tangible investments. A project which is already underway is a Chinese high-speed railway link between Belgrade and Budapest. The People's Republic of China is a new and very important regional player (Góralczyk). China has launched a variety of collaborative partnerships, such as $16+1^{2}$ (which includes Poland) or the New Silk Road ${ }^{3}$ and construction of transportation routes to Europe, choosing Serbia as is main partner. Belgrade became the site for one of the largest infrastructural projects, a new bridge over the Danube River, which was built thanks to cheap loans and labour from China (Grószczyński, 2016). In early April, Serbia announced that it would sell its Smederevo steel plant to China's Hebei steel company. The European Union has also drawn Serbia's attention to its internal problems. In its annual report on candidate countries (published on 10 November 2015), the EU stressed the need for appropriate implementation of its legislation, especially as it related to the rule of law or reducing the use of public institutions for political in-fighting. The EU also singled out corruption and organised crime, both of which continue to be among the country's major problems (Commission Staff...). For Serbia, as for Kosovo, this was

${ }^{2}$ China's " $16+1$ " formula of regional cooperation with Central and Eastern Europe (CEE) countries dates back to 2012. The Chinese use a very broad definition of CEE which they see as 16 countries of the post-communist bloc comprising Estonia, Latvia, Lithuania, Poland, Czech Republic, Slovakia, Hungary, Romania, Bulgaria, Slovenia, Croatia, Serbia, Bosnia and Herzegovina, Montenegro, Albania and Macedonia. For more details, see: M. Kaczmarski, Chiny-Europa Środkowo-Wschodnia: „, 16+1” widziane z Pekinu.

${ }^{3}$ The New Silk Road concept of land and sea-based routes was first presented by the Chinese leader Xi Jinping in Autumn 2013. Initially, the idea was to create a network of infrastructural links, mostly transport routes, between China and its most important economic partner, Europe. The concept grew in importance throughout 2014, eventually becoming a key tool of the Chinese foreign policy, mostly as an instrument of public diplomacy and soft power. The concept is designed to legitimise and facilitate Chinese influence in transit countries along the route to Western Europe, that is to say, in the Middle East (Arab states, Israel, Turkey), the Horn of Africa (Kenya), and in Central Europe (Balkans, Visegrad Group countries). For more details, see M. Kaczmarski, Nowy Jedwabny Szlak: uniwersalne narzędzie chińskiej polityki. 
a breakthrough year, even though it's Serbs who are further down the accession path. The country is ready to open the chapters on the rule of law and has signed an agreement that normalises its relations with Kosovo, which was required to complete the negotiation process (formally, part of Chapter 35 "Other business"). In April, the prime ministers of Serbia and Kosovo, Ivica Daczić and Hashim Thaci, signed an agreement under the EU auspices to normalize the relations between the two countries. Kosovo, a former Serbian province mostly populated by Albanians, declared independence in 2008, which Belgrade has never recognised. The agreement does not provide for Serbia's formal recognition of Kosovo's sovereignty, but it regulates the situation in northern Kosovo which has a 40,000-strong Serbian minority. Both parties have also agreed not to block each other on their path to EU membership.

While praising Serbian determination on its road to accession, the European Commission has stressed that the good legislation the country enacted in the last year in order to reduce political parties' influence in public institutions or improve the rule of law must now be properly implemented. As is characteristic of other countries in the region, Serbia, too, has a problem with organised crime and corruption. ${ }^{4}$ The support for EU within Serbia is at approx. 50 per cent. The issue is a very difficult one, however, because of the quite protracted integration process. Also, the European Union has been plunged into crisis and as such is becoming less attractive for the Serbian society, with membership offering weaker prospects for a radical improvement of the country's situation. Serbia has also seen a slight increase in authoritarian tendencies. Prime minister Vucić has won not just because the opposition is divided and provides no real alternative, but also because he has brought media under his control. He is using his party's influence and has relied on public institutions during the election campaign. Vucić is sure he will finish the negotiations within four years. What is crucial is whether at the end of the day the EU will impose a condition on Serbia to recognise Kosovo's independence. So far, nobody has put that requirement forward.

\section{Bibliography}

Commission Staff Working Document, Serbia 2016 Report, Accompanying the document, Communication from the Commission to the European Parliament, the Council, the European Economic and Social Committee and the Committee of the Regions 2016 Communication on EU Enlargement Policy.

Góralczyk B., Bałkany będa się radykalizować. Sytuację moga wykorzystać Chiny, http://forsal.pl/ artykuly/942689, balkany-o-ktorych-nie-przypomni-sobie-europa-beda-sie-radykalizowac.html.

Grabkowska S., Grabkowski R. (red.) (2008), Zasady zmian konstytucji w państwach europejskich. Stan prawny na 1.01.2008 r., Warszawa.

Grószczyński O. (2016), Xi Jinping w czasie wizyty w Serbii otworzy nowy rozdział w stosunkach dwustronnych, Polska Agencja Informacyjna 15.06.2016.

${ }^{4}$ Less of a worry to Montenegrins and Macedonians, corruption is more of concern for Serbs, Albanians and the people of Kosovo (the majority of whom are Albanians). According to Transparency International's 2015 Corruption Perceptions Index (CPI) the situation has deteriorated most in Macedonia. As per the latest report, the CPI was 42 for Macedonia, 40 for Serbia, 38 for Bosnia and Herzegovina, 36 for Albania, and 33 for Kosovo (Denmark tops the list as the "cleanest" country at 91; Poland - 62). 
http://www.rik.parlament.gov.rs/aktivnosti-konferencije.php\#a10.

Kokot M. (2016), Radavan Karadzić winny zbrodni przeciwko ludzkości, "Gazeta Wyborcza" 24.03.2016.

Komunikat Komisji do Parlamentu Europejskiego i Rady w sprawie studium wykonalności dotyczqcego uktadu o stabilizacji i stowarzyszeniu między Unia Europejskq a Kosowem, COM/2012/0602 final, http://eur-lex.europa.eu/legal-content/pl/TXT/?uri=CELEX:52012DC0602.

Konstytucja Republiki Serbii.

Korzeniewska-Wiszniewska M. (2008), Serbia pod rzq̨dami Slobodana Miloševicia, Kraków.

Kosowo - przed ostatecznym rozwiazaniem (2008), Prace OSW, Warszawa.

Kownacki R., Żornaczuk T. (2010), Opinia doradcza MTS w sprawie deklaracji niepodległości Kosowa, "Biuletyn PISM", nr 108, 23.07.2010.

Lubik-Reczek N. (2011), Państwa postjugosłowiańskie wobec członkostwa w Unii Europejskiej i NATO (Analiza porównawcza), Torun.

Mihajić M. (2008), Bałkański kompleks niestabilności i bezpieczeństwa, in: Bezpieczeństwo międzynarodowe po zimnej wojnie, ed. R. Zięba, Warszawa.

Proglašena prva lista-Uz SNS sportisti, pevači, http://mondo.rs/a881803/Info/Srbija/Izbori-Proglasena-lista-SNS-Aleksandar-Vucic-Srbija-pobedjuje.html.

Republika Serbii - wybory parlamentarne, www.e-polityka.pl/a.6558.d.56.Kronika_wyborcza_ styczeń_2007.html.

Serbia: aresztowanie ostatniego z poszukiwanych za zbrodnie wojenne przez ICTY, https://www.osw. waw.pl/pl/publikacje/analizy/2011-07-27/serbia-aresztowanie-ostatniego-z-poszukiwanychza-zbrodnie-wojenne.

Serbia: Oficjalne wyniki wyborów parlamentarnych, http://balkanekspres.blog.pl/2014/03/25/serbiaoficjalne-wyniki-wyborow-parlamentarnych/.

SNS $i$ Vućić wygrywaja wybory w Serbii, www.Balkanistyka.org/sns-i-vucic-wygrywaja-wybory-wserbii/.

Szpala M. (2010), Regionalne konsekwencje opinii doradczej MTS w sprawie Kosowa, OSW, 4.08.2010.

Szpala M. (2012), Potrójne wybory w Serbii nie zmieniaja proeuropejskiego kursu, OSW, 9.05.2012.

Śliwa R. (2008), Międzynarodowy trybunat ds. ścigania osób odpowiedzialnych za poważne łamanie międzynarodowych praw człowieka na terytorium bytej Jugosławii poczqwszy od 1991 r., Kraków.

\section{Serbskie wybory: droga ku Europie?}

\section{Streszczenie}

Republika Serbii powstała 5 czerwca 2006 r. jako spadkobierczyni państwa pod nazwą Serbia i Czarnogóra, które rozpadło się po ogłoszeniu niepodległości przez Czarnogórę 3 czerwca 2006 r. Serbia i Czarnogóra jako związek dwóch republik została proklamowana 4 lutego 2003 r. Zastapił on utworzoną 27 kwietnia 1992 r. Federacyjną Republikę Jugosławii, w skład której wchodziły Republika Serbii i Republika Czarnogóry. Kluczowym celem niniejszych rozważań, jest udzielenie odpowiedzi na pytania: czy wybory w Serbii zapewnią kontynuację drogi do Europy oraz czy Serbia jest gotowa na to członkostwo? Integracja tego kraju z Unią Europejską zacieśniła się, kiedy do władzy doszedł po wyborach prezydenckich w 2004 roku proeuropejski prezydent Boris Tadić. Największymi przeszkodami w przystapieniu Serbii do UE są, po pierwsze, sprawa niepodległości Kosowa, a po drugie, rozliczenie przed Trybunałem w Hadze osób odpowiedzialnych za zbrodnie wojenne popełnione w czasie wojny w byłej Jugosławii. Proces integracji Serbii z Unią Europejską trwa już dość długo. Serbowie 
chcą zakończyć negocjacje w 2019 r., by formalnie dołączyć do Unii Europejskiej w 2020 r. - Komisja Europejska ogłosiła bowiem moratorium na przyjmowanie nowych członków w trakcie obecnej kadencji swojej i Parlamentu Europejskiego, trwających właśnie do 2019 r.W kwietniu premierzy Serbii i Kosowa: Ivica Daczić i Hashim Thaci podpisali porozumienie, wynegocjowane pod auspicjami UE, w sprawie normalizacji stosunków między oboma państwami. Kosowo, dawna serbska prowincja zamieszkana w większości przez Albańczyków, ogłosiło niepodległość w 2008 roku, czego Belgrad nigdy nie uznał. Porozumienie to nie przewiduje formalnego uznania przez Serbię suwerenności Kosowa, reguluje natomiast sytuację w północnej części Kosowa, którą zamieszkuje 40-tysięczna mniejszość serbska. Obie strony zobowiązały się także w tym dokumencie do nieblokowania sobie nawzajem drogi do członkostwa w Unii Europejskiej.

Słowa kluczowe: wybory w Serbii, partie polityczne, Unia Europejska, Kosowo 